International Journal of Engineering \& Technology, $7(2.23)(2018) 143-147$
International Journal of Engineering \& Technology
WPC
Website www.sciencepubco.com/index.php/IJET
Research paper

\title{
Comparison of solid biofuels produced from olive pomace with two different conversion methods: torrefaction and hydrothermal carbonization
}

\author{
Selin Y. Gultekin *, Hayati Olgun, Melih S. Celiktas \\ Solar Energy Institute, Ege University, 35100 Bornova-Izmir, Turkey \\ *Corresponding author E-mail: selingultekin13@gmail.com
}

\begin{abstract}
Olive pomace is a by-product of olive oil production process and has the potential to be a solid biofuel after thermal treatment. In this study, olive pomace was treated by two thermal conversion methods: hydrothermal carbonization (HTC) and torrefaction. Experiments were carried out under the temperature values of $250,275,300$ and $350^{\circ} \mathrm{C}$; reaction times of 10,20 and 30 minutes for torrefaction and temperature values of 180, 200 and $220^{\circ} \mathrm{C}$; reaction time of 2, 3 and 4 hours for HTC. Products with the same energy yield value (62 \%) obtained the higher heating values of 23.73 and $25.20 \mathrm{MJ} / \mathrm{kg}$ for torrefaction $\left(275^{\circ} \mathrm{C}\right.$ for 20 minutes $)$ and hydrothermal carbonization $\left(220^{\circ} \mathrm{C}\right.$ for 2 hours), respectively. Hydrothermal carbonization method has the potential to produce chars at lower temperature values and without a drying process; and obtain products with improved higher heating values, energy yields and atomic $\mathrm{O} / \mathrm{C}$ and $\mathrm{H} / \mathrm{C}$ ratios compare to torrefaction products.
\end{abstract}

Keywords: Torrefaction, hydrothermal carbonization, olive pomace, fixed carbon, biomass

\section{Introduction}

The world energy demand is mostly met by fossil fuels. According to International Energy Agency, the world share of energy sources is petroleum $37 \%$, natural gas $29 \%$, coal $15 \%$, renewable energies $10 \%$ and nuclear energy $9 \%$ for 2016. It is indicated in IEA 2016 scenario that fossil fuels' share will continue to be important in 2040. However, market prices for these fuels will rise with the reducing amount of reserves [1]. Renewable and sustainable resources are thought to be significant alternatives in this foreseen energy crisis. Among all the sustainable energies, biomass energy has the broad availability worldwide and this makes it an interesting option [2]. On the other hand, as an energy resource, biomass has its disadvantages such as structural heterogeneity, nonuniform physical properties, low energy density, hygroscopic nature, and low bulk density [3]. These characteristics prevent the use of biomass instead of fossil fuels. Consequently, biomass requires a pretreatment method before the thermochemical conversion. Hydrothermal carbonization (HTC) and torrefaction treatments are the two most useful methods with relatively low temperature requirements within all other thermochemical conversion processes [4].

HTC process occurs at temperature values between $180-260{ }^{\circ} \mathrm{C}$ and biomass is mixed with subcritical water so that the products are not affected by the high moisture content. Hydrothermal carbonization has the ability to deal with extremely wet biomass re- sources such as sewage sludge, paper mill and also forestry processing residues and agricultural wastes [5]. It is used to produce a solid fuel called hydrochar which has reduced $\mathrm{O} / \mathrm{C}$ and $\mathrm{H} / \mathrm{C}$ ratios, increased calorific value and enhanced hydrophobicity [6].

Torrefaction is a thermochemical pretreatment of biomass in the temperature range of $200-300{ }^{\circ} \mathrm{C}$, under the inert gas environment for residence time of minutes to couple of hours [7]. Advantages of torrefied biomass are decreased moisture content, enhanced resistance to water damage and microbial growth, and increased friability [8].

Olive oil extraction industry has an important share in economy of Mediterranean countries such as Turkey, Spain, Italy and Greece [9]. It is estimated that the world-wide production of olive oil was about 3 million tons for the harvest period of 2013-2014 [10]. The rapid increase in the amount of wastes generated in this process has caused serious environmental issues due to wastes' high organic matter content and its phytotoxicity [11]. Olive mills not only produce significant quantities of wastewater but solid wastes as well [12]. Olive pomace is found to have proper higher heating values. It is possible to remove its moisture and volatile matter content and obtain an energy-dense solid biofuel.

In this study, it is aimed to use hydrothermal carbonization and torrefaction methods to produce energy-dense solid biofuels from olive pomace and compare them by their elemental, proximate and calorific properties. Hydrothermal carbonization and torrefaction products are called as hydrochar and biochar, respectively. There 
were some studies [13,14, 15, 16 and 17] carried out with olive pomace but none of them included both hydrothermal carbonization and torrefaction methods and their product comparison. The main objective of this study is to show fuel characteristics of olive pomace and it is potential to generate an alternative biofuel by these two methods.

\section{Material and Methods}

\subsection{Material}

Olive pomace was taken from Germencik, Aydın, Turkey. The material had $40 \%$ of moisture content when it was arrived. It was dried in a hot-room $\left(37{ }^{\circ} \mathrm{C}\right)$ until its moisture content was decreased less than $10 \%$ for torrefaction reactions. Particle sizes of olive pomace were over $1 \mathrm{~mm}$.

\subsection{Hydrothermal Carbonization Experiments}

Hydrothermal carbonization experiments were generated in a 100 ml stainless steel reactor (Amar Equipment Pvt. Ltd.). Biomass and deionized water mixture were loaded in the reactor as $10 \%$ solid/liquid ratio. The reactor was heated with an electric heater to desired temperature $\left(180,200\right.$ and $220{ }^{\circ} \mathrm{C}$ ) and held for desired reaction time (2, 3 and 4 hours). Inside the reactor, increasing temperature was created a pressure value between 8 to 10 bars After the reaction, the reactor was cooled to room temperature by the automatic cooler. Remaining products, hydrochars, were dried at $104{ }^{\circ} \mathrm{C}$ for 24 hours and kept for further analyses.

\subsection{Torrefaction Experiments}

Torrefaction experiments were carried out in a pilot scale continuous screw type torrefaction reactor with $5 \mathrm{~kg} / \mathrm{h}$ feeding capacity in Solar Energy Institute of Ege University, Turkey. The torrefaction system consists four screw units: the first screw is the biomass feeder, the second is the biomass dryer and pre-heater, the third is the torrefaction reactor and the forth is the cooler. First, the dryer (around $120^{\circ} \mathrm{C}$ ) and torrefaction $\left(250,275,300\right.$ and $350{ }^{\circ} \mathrm{C}$ ) reactors were heated to the desired temperatures. Then, the biomass feed screw was started. All experiments were conducted in an inert atmosphere. Torrefaction reaction times were determined to be 10, 20 and 30 minutes for each temperature degree. After they were cooled in the system, biochars were collected. Obtained biochars were kept for further analyses.

\subsection{Product Characterization}

Each analysis was repeated for three times. Biomass, biochars and hydrochars were analyzed for ash, volatile matter contents by respectively ASTM D 1102-84 and ASTM E 897-82 standards. Fixed carbon content was calculated from ash and volatile matter results. The carbon $(\mathrm{C})$, hydrogen $(\mathrm{H})$ and nitrogen $(\mathrm{N})$ contents were measure with Leco Tru Spec (USA) by ASTM-D5373 standards. Oxygen contents were calculated from the equation. Sulfur (S) contents were also measured by ASTM D-4239 standards. The higher heating values of the biomass and products were calculated with bomb calorimeter (Parr Instrument Co., Model 6300, Moline, IL, USA).

\section{Results and Discussion}

\subsection{Fuel Characteristics of Chars}

Proximate analyses results of the products and raw material are given in Table 1. The ash, volatile matter and fixed carbon values of biochars were observed to change dramatically with the increase of temperature between 250 and $350{ }^{\circ} \mathrm{C}$ for torrefaction reactions. As the temperature increased, the amount of volatile matter decreased and fixed carbon and ash contents increased.

\begin{tabular}{|c|c|c|c|c|}
\hline & Parameters & $\operatorname{Ash}(\%)$ & $\begin{array}{c}\text { Volatile } \\
\text { Matter } \\
(\%)\end{array}$ & $\begin{array}{c}\text { Fixed } \\
\text { Carbon } \\
(\%)\end{array}$ \\
\hline Raw & & 1.61 & 94.11 & 4.28 \\
\hline \multirow{12}{*}{ 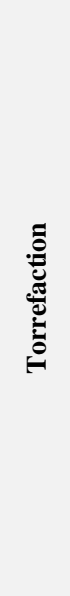 } & $250{ }^{\circ} \mathrm{C} 10 \mathrm{~min}$ & 2.35 & 91.64 & 6.01 \\
\hline & $275^{\circ} \mathrm{C} 10 \mathrm{~min}$ & 3.63 & 74.74 & 21.63 \\
\hline & $300{ }^{\circ} \mathrm{C} 10 \mathrm{~min}$ & 6.83 & 48.66 & 44.51 \\
\hline & $350{ }^{\circ} \mathrm{C} 10 \mathrm{~min}$ & 14.27 & 34.36 & 51.37 \\
\hline & $250{ }^{\circ} \mathrm{C} 20 \mathrm{~min}$ & 3.89 & 69.50 & 26.61 \\
\hline & $275^{\circ} \mathrm{C} 20 \mathrm{~min}$ & 4.42 & 67.46 & 28.12 \\
\hline & $300{ }^{\circ} \mathrm{C} 20 \mathrm{~min}$ & 13.50 & 44.17 & 42.33 \\
\hline & $350{ }^{\circ} \mathrm{C} 20 \mathrm{~min}$ & 14.68 & 34.39 & 50.93 \\
\hline & $250{ }^{\circ} \mathrm{C} 30 \mathrm{~min}$ & 3.14 & 66.48 & 30.38 \\
\hline & $275^{\circ} \mathrm{C} 30 \mathrm{~min}$ & 5.74 & 56.61 & 37.65 \\
\hline & $300{ }^{\circ} \mathrm{C} 30 \mathrm{~min}$ & 19.34 & 38.98 & 41.68 \\
\hline & $350{ }^{\circ} \mathrm{C} 30 \mathrm{~min}$ & 20.46 & 33.19 & 46.35 \\
\hline \multirow{9}{*}{ 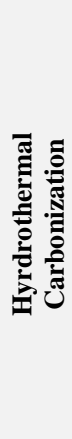 } & $180^{\circ} \mathrm{C} 2 \mathrm{~h}$ & 0.50 & 79.75 & 19.75 \\
\hline & $180{ }^{\circ} \mathrm{C} 3 \mathrm{~h}$ & 0.64 & 78.35 & 21.01 \\
\hline & $180{ }^{\circ} \mathrm{C} 4 \mathrm{~h}$ & 0.51 & 77.27 & 22.22 \\
\hline & $200{ }^{\circ} \mathrm{C} 2 \mathrm{~h}$ & 0.81 & 74.88 & 24.30 \\
\hline & $200{ }^{\circ} \mathrm{C} 3 \mathrm{~h}$ & 0.37 & 74.88 & 24.75 \\
\hline & $200{ }^{\circ} \mathrm{C} 4 \mathrm{~h}$ & 0.38 & 74.38 & 25.24 \\
\hline & $220{ }^{\circ} \mathrm{C} 2 \mathrm{~h}$ & 1.25 & 67.90 & 30.86 \\
\hline & $220{ }^{\circ} \mathrm{C} 3 \mathrm{~h}$ & 0.84 & 62.32 & 36.84 \\
\hline & $220{ }^{\circ} \mathrm{C} 4 \mathrm{~h}$ & 0.69 & 61.81 & 37.50 \\
\hline
\end{tabular}

The HTC process provided lower ash contents. However, a consistent decrease with temperature or reaction time wasn't observed. Similar decreases for the HTC of grape pomace and mischantus samples were also observed in other studies $[18,19]$. In this study, ash contents of hydrochars slightly changed (Figure 1).

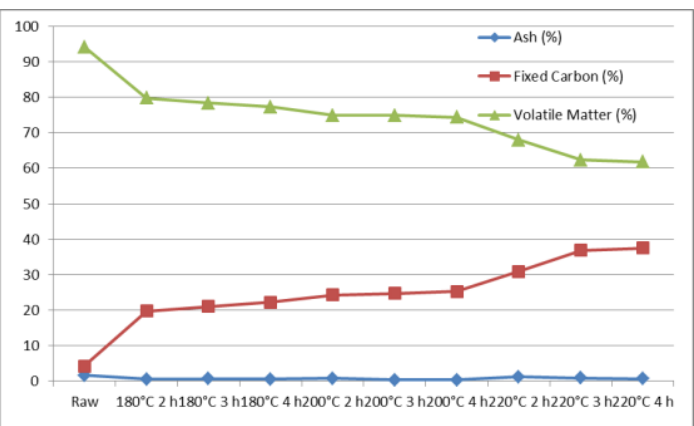

Fig.1: Ash, Fixed Carbon and Volatile Matter Contents of Hydrochar

On the other hand, biochars' ash contents highly increased as in literature for olive pomace and grape pomace $[15,18]$. The resolution of inorganic matters in subcritical water is the reason for these different results for ash contents. In hydrothermal carbonization process, subcritical water provides the removal of inorganic materials from the biomass and the ash content of hydrochar decreases [20]. 
On the contrary, inorganic matter content increased during the torrefaction process (Figure 2). Hydrothermal carbonization products have the advantage of low ash content to prevent fouling and slagging in processes such as combustion, gasification and pyrolysis [20, 21 and 22]. The results of proximate analyses generally showed the characteristic similarities between converted products and coal. In this study, it is observed that volatile matter contents decreased and fixed carbon contents increased for both methods. Volatile matter and fixed carbon contents were seemed to be compatible with other studies [17]. These processes are known to be efficient on reducing the volatile matter content of biomass. The volatile matter and fixed carbon contents of HTC processes $\left(220{ }^{\circ} \mathrm{C} 3 \mathrm{~h}\right.$ and $\left.4 \mathrm{~h}\right)$ and torrefaction process $\left(275^{\circ} \mathrm{C}, 30 \mathrm{~min}\right)$ were found to be similar. It is known that high volatile matter content of biomass causes low combustion performance and release of environmentally hazardous substances [23]. The difference between volatile matter contents of biomass and coal brings on separated combustion zones [20].

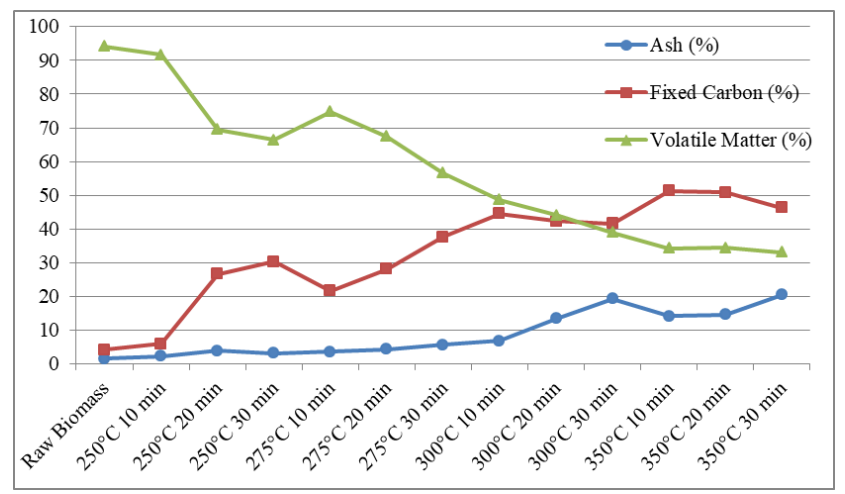

Fig.2: Ash, Fixed Carbon and Volatile Matter Contents of Biochar

Elemental analyses results of hydrochar, biochar and raw biomass are shown in Table 2. The higher carbon and lower oxygen contents of converted products provided enhanced higher heating values. In HTC processes, higher carbon contents were obtained under the elevated temperature conditions. However, the change of reaction time had only a slight effect on carbon contents. On the other hand, for the torrefaction processes, carbon contents rose with the increase of both temperature and reaction time.

The increase on the temperature, the decrease on oxygen content and a slight change on hydrogen content indicates the carbonization for both methods. Biochar of $300{ }^{\circ} \mathrm{C}, 30 \mathrm{~min}$ and hydrochar of $220{ }^{\circ} \mathrm{C}, 4 \mathrm{~h}$ provided approximate values of carbon contents, respectively $63.52 \%$ and $63.01 \%$. It is clearly seen that the effect of carbonization on hydrochar under the lower temperatures was more significant.

The reaction times of HTC processes didn't have an important effect on carbon content of olive pomace. In literature, it was studied with olive pomace on 180,200 and $220{ }^{\circ} \mathrm{C}$ for 30 minutes and observed carbon contents increased from $50.3 \%$ to 55.3, 58.1 and $60 \%$ [17]. These results didn't differ from the results for this study, so it is possible to recommend lower reaction times for the HTC process of olive pomace.
Table 2: Elemental Analyses Results of Bioproducts

\begin{tabular}{|c|c|c|c|c|c|c|}
\hline & Parameters & $\mathrm{C}(\%)$ & $\underset{(\%)}{\mathbf{H}}$ & $\begin{array}{c}\mathrm{N} \\
(\%)\end{array}$ & $\underset{(\%)}{S}$ & $\underset{(\%)}{\mathbf{O}}$ \\
\hline Raw & & 49.61 & 6.40 & 0.58 & 0.05 & 41.76 \\
\hline \multirow{12}{*}{ 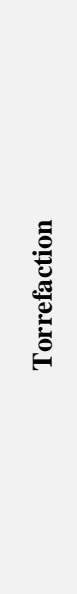 } & $250{ }^{\circ} \mathrm{C} 10 \mathrm{~min}$ & 49.93 & 6.44 & 0.70 & 0.05 & 40.54 \\
\hline & $275^{\circ} \mathrm{C} 10 \mathrm{~min}$ & 49.86 & 6.33 & 0.68 & 0.05 & 39.45 \\
\hline & $300{ }^{\circ} \mathrm{C} 10 \mathrm{~min}$ & 58.42 & 4.68 & 0.91 & 0.03 & 29.14 \\
\hline & $350{ }^{\circ} \mathrm{C} 10 \mathrm{~min}$ & 61.34 & 5.57 & 1.10 & 0.04 & 17.68 \\
\hline & $250{ }^{\circ} \mathrm{C} 20 \mathrm{~min}$ & 53.66 & 6.06 & 0.86 & 0.03 & 35.50 \\
\hline & $275^{\circ} \mathrm{C} 20 \mathrm{~min}$ & 54.95 & 6.08 & 1.11 & 0.05 & 33.40 \\
\hline & $300{ }^{\circ} \mathrm{C} 20 \mathrm{~min}$ & 59.28 & 4.77 & 1.26 & 0.02 & 21.17 \\
\hline & $350{ }^{\circ} \mathrm{C} 20 \mathrm{~min}$ & 63.18 & 5.26 & 1.15 & 0.02 & 15.70 \\
\hline & $250{ }^{\circ} \mathrm{C} 30 \mathrm{~min}$ & 54.28 & 5.80 & 0.95 & 0.03 & 35.80 \\
\hline & $275^{\circ} \mathrm{C} 30 \mathrm{~min}$ & 59.30 & 5.81 & 1.21 & 0.03 & 27.92 \\
\hline & $300{ }^{\circ} \mathrm{C} 30 \mathrm{~min}$ & 63.52 & 5.00 & 1.04 & 0.03 & 11.07 \\
\hline & $350{ }^{\circ} \mathrm{C} 30 \mathrm{~min}$ & 68.16 & 4.70 & 1.26 & 0.03 & 5.39 \\
\hline \multirow{9}{*}{ 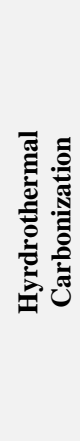 } & $180{ }^{\circ} \mathrm{C} 2 \mathrm{~h}$ & 54.28 & 6.69 & 1.15 & 0.03 & 37.35 \\
\hline & $180{ }^{\circ} \mathrm{C} 3 \mathrm{~h}$ & 53.36 & 6.49 & 0.82 & 0.03 & 38.67 \\
\hline & $180{ }^{\circ} \mathrm{C} 4 \mathrm{~h}$ & 54.46 & 6.67 & 1.04 & 0.05 & 37.27 \\
\hline & $200{ }^{\circ} \mathrm{C} 2 \mathrm{~h}$ & 56.13 & 6.69 & 1.05 & 0.06 & 35.25 \\
\hline & $200{ }^{\circ} \mathrm{C} 3 \mathrm{~h}$ & 56.07 & 6.51 & 0.96 & 0.05 & 36.04 \\
\hline & $200{ }^{\circ} \mathrm{C} 4 \mathrm{~h}$ & 57.01 & 6.55 & 1.00 & 0.05 & 35.01 \\
\hline & $220{ }^{\circ} \mathrm{C} 2 \mathrm{~h}$ & 59.82 & 6.54 & 1.16 & 0.05 & 31.18 \\
\hline & $220^{\circ} \mathrm{C} 3 \mathrm{~h}$ & 62.37 & 6.39 & 1.19 & 0.07 & 29.14 \\
\hline & $220{ }^{\circ} \mathrm{C} 4 \mathrm{~h}$ & 63.01 & 6.42 & 1.15 & 0.06 & 28.67 \\
\hline
\end{tabular}

\subsection{Van Krevelen Graphs}

Atomic $\mathrm{H} / \mathrm{C}$ and $\mathrm{O} / \mathrm{C}$ ratios of biochar and hydrochar were shown on van Krevelen graphs to observe the changes on atomic content of olive pomace (Figure 3 and 4, respectively). On HTC processes, atomic $\mathrm{O} / \mathrm{C}$ and $\mathrm{H} / \mathrm{C}$ ratios clearly reduced with the increase on the temperature and a coal-like product was generated.

A linear correlation can be observed between the hydrogen/carbon and oxygen/carbon ratios as in other studies [24, 25]. Torrefaction processes which occured at lower temperatures $\left(250\right.$ and $\left.275{ }^{\circ} \mathrm{C}\right)$ had higher $\mathrm{H} / \mathrm{C}$ and $\mathrm{O} / \mathrm{C}$ ratios than hydrochar and the results were approximate to raw biomass's ratios.

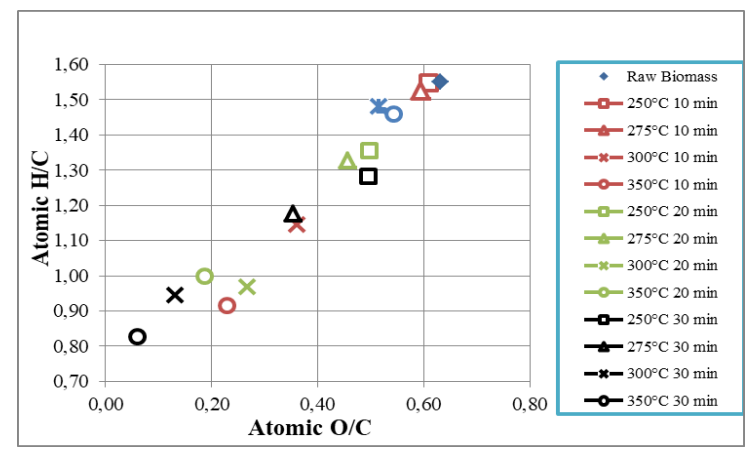

Fig.3: Atomic O/C and $\mathrm{H} / \mathrm{C}$ ratios of biochar

Hydrochars of $220^{\circ} \mathrm{C}, 3 \mathrm{~h}$ and $4 \mathrm{~h}$ had $\mathrm{H} / \mathrm{C}$ ratios of 1.23 and 1.22 ; $\mathrm{O} / \mathrm{C}$ ratios of 0.35 and 0.34 . Biochar of $275{ }^{\circ} \mathrm{C} 30 \mathrm{~min}$ also had $\mathrm{H} / \mathrm{C}$ ratio of 1.17 and $\mathrm{O} / \mathrm{C} 0.35 ; \mathrm{H} / \mathrm{C}$ ratio of 1.09 and $\mathrm{O} / \mathrm{C}$ ratio of 0.30 for $300{ }^{\circ} \mathrm{C} 10 \mathrm{~min}$ and $\mathrm{H} / \mathrm{C}$ ratio of 0.97 and $\mathrm{O} / \mathrm{C}$ ratio of 0.27 for $300^{\circ} \mathrm{C} 20$ min. Lignite has the atomic $\mathrm{H} / \mathrm{C}$ and $\mathrm{O} / \mathrm{C}$ ratios between $0.8-1.3$ and $0.2-0.38$ which shows that these products are comparable with lignite as a solid fuel. Lower $\mathrm{H} / \mathrm{C}$ and $\mathrm{O} / \mathrm{C}$ 
ratios indicate the water vapor of biomass had removed and smaller amounts of smoke will be observed during combustion [8].

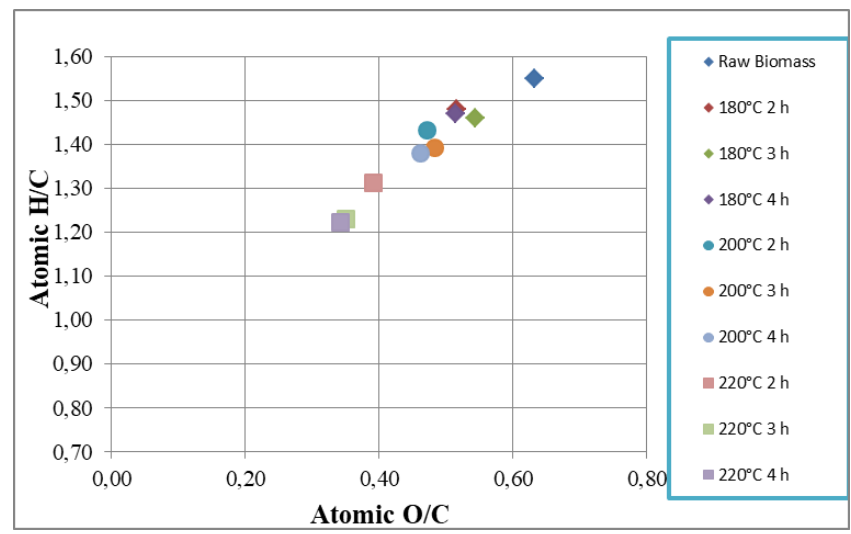

Fig.4: Atomic $\mathrm{O} / \mathrm{C}$ and $\mathrm{H} / \mathrm{C}$ ratios of hydrochar

\subsection{Higher Heating Value, Energy and Mass Yields}

In this study, biochar yields were observed $88.87 \%$ and $40.02 \%$ for temperatures of $250{ }^{\circ} \mathrm{C}$ and $300{ }^{\circ} \mathrm{C}$ (Table 3). The dramatic decrease of biochar yield with the increasing temperature is due to the decomposition of cellulose at $300{ }^{\circ} \mathrm{C}[26,27]$. The mass yields of torrefaction reaction at $250{ }^{\circ} \mathrm{C}$ and 20 minutes and HTC reaction at $180{ }^{\circ} \mathrm{C}$ and $2 \mathrm{~h}$ were measured as respectively $68 \%$ and $63 \%$. The main reactions occur in both processes were dehydration and decarboxylation. Additionally, during the HTC, extractable materials (both organics and inorganics) were separated simultaneously due to their high solubility ratios in subcritical water [28]. It is the reason for lower mass yields of hydrochars.

Energy yields were measured according to equation (1):

Energy Yield=Mass Yield $\times$ [(Product's HHV)/(Raw Biomass' HHV $)]$

During HTC process, energy densities were increased from 1.09 to 1.32 between $180-220{ }^{\circ} \mathrm{C}$ (Table 3 ). On the other hand, energy yields decreased with the increasing temperature values. At $220{ }^{\circ} \mathrm{C}$, the decrease mostly depended on reduced mass yields. It was studied on pine between $215-295{ }^{\circ} \mathrm{C}$ and energy yields were observed to increase from $70 \%$ to $\% 77$ [29]. On the other hand, in another study on coconut and eucalyptus leaves (temperatures between $200-300{ }^{\circ} \mathrm{C}$ ), energy yields decreased respectively from $76.67 \%$ to $65 \%$ and from $87.34 \%$ to $61.32 \%$ [30]. These opposite results were because of the difference between the biomass resources. Biochars obtained at $250{ }^{\circ} \mathrm{C} 10 \mathrm{~min}$ had the energy yield of $88.87 \%$. However, it had a lower higher heating value than the hydrochar of $180{ }^{\circ} \mathrm{C}$ and $2 \mathrm{~h}$. It is crucial for these processes to provide increased mass yields to obtain higher energy yields. Frankly, HTC process seems to generate higher energy density. Energy contents of hydrochars were between 22.14 and $26.94 \mathrm{MJ} / \mathrm{kg}$.
Table 3: HHV, Mass Yield, Energy Yield and Energy Density Values

\begin{tabular}{|c|c|c|c|c|c|}
\hline \multirow[b]{2}{*}{ Raw } & Parameters & $\begin{array}{c}\text { HHV } \\
(\mathbf{M J} / \mathbf{k g})\end{array}$ & $\begin{array}{c}\text { Mass } \\
\text { Yield } \\
(\%)\end{array}$ & $\begin{array}{c}\text { Energy } \\
\text { Yield } \\
(\%)\end{array}$ & $\begin{array}{l}\text { Energy } \\
\text { Density }\end{array}$ \\
\hline & & 20,34 & & & \\
\hline \multirow{12}{*}{ 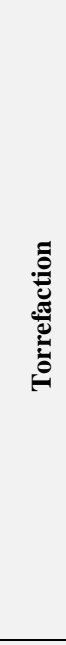 } & $250{ }^{\circ} \mathrm{C} 10 \mathrm{~min}$ & 20,58 & 87,85 & 88,87 & 1,01 \\
\hline & $275^{\circ} \mathrm{C} 10 \mathrm{~min}$ & 22,68 & 74,24 & 82,79 & 1,12 \\
\hline & $300{ }^{\circ} \mathrm{C} 10 \mathrm{~min}$ & 23,08 & 35,29 & 40,04 & 1,13 \\
\hline & $350{ }^{\circ} \mathrm{C} 10 \mathrm{~min}$ & 28,64 & 29,30 & 41,25 & 1,41 \\
\hline & $250{ }^{\circ} \mathrm{C} 20 \mathrm{~min}$ & 20,78 & 68,99 & 70,49 & 1,02 \\
\hline & $275^{\circ} \mathrm{C} 20 \mathrm{~min}$ & 23,73 & 53,42 & 62,32 & 1,17 \\
\hline & $300{ }^{\circ} \mathrm{C} 20 \mathrm{~min}$ & 25,33 & 34,37 & 42,80 & 1,25 \\
\hline & $350{ }^{\circ} \mathrm{C} 20 \mathrm{~min}$ & 29,41 & 29,85 & 43,16 & 1,45 \\
\hline & $250{ }^{\circ} \mathrm{C} 30 \mathrm{~min}$ & 20,78 & 37,73 & 49,62 & 1,32 \\
\hline & $275^{\circ} \mathrm{C} 30 \mathrm{~min}$ & 23,73 & 34,77 & 49,11 & 1,41 \\
\hline & $300{ }^{\circ} \mathrm{C} 30 \mathrm{~min}$ & 25,33 & 28,29 & 40,24 & 1,42 \\
\hline & $350{ }^{\circ} \mathrm{C} 30 \mathrm{~min}$ & 29,41 & 29,24 & 42,41 & 1,45 \\
\hline \multirow{9}{*}{ U } & $180^{\circ} \mathrm{C} 2 \mathrm{~h}$ & 22,14 & 63,10 & 68,69 & 1,09 \\
\hline & $180{ }^{\circ} \mathrm{C} 3 h$ & 22,26 & 60,04 & 65,72 & 1,09 \\
\hline & $180{ }^{\circ} \mathrm{C} 4 \mathrm{~h}$ & 22,34 & 59,99 & 65,90 & 1,10 \\
\hline & $200{ }^{\circ} \mathrm{C} 2 \mathrm{~h}$ & 23,29 & 59,50 & 68,13 & 1,15 \\
\hline & $200^{\circ} \mathrm{C} 3 \mathrm{~h}$ & 23,38 & 57,81 & 66,44 & 1,15 \\
\hline & $200{ }^{\circ} \mathrm{C} 4 \mathrm{~h}$ & 23,41 & 57,30 & 65,95 & 1,15 \\
\hline & $220{ }^{\circ} \mathrm{C} 2 \mathrm{~h}$ & 25,20 & 50,08 & 62,05 & 1,24 \\
\hline & $220{ }^{\circ} \mathrm{C} 3 \mathrm{~h}$ & 26,32 & 45,06 & 58,30 & 1,29 \\
\hline & $220^{\circ} \mathrm{C} 4 \mathrm{~h}$ & 26,94 & 44,89 & 59,46 & 1,32 \\
\hline
\end{tabular}

In another study with olive pomace, the higher heating values of $22.1,23.3$ and $24.3 \mathrm{MJ} / \mathrm{kg}$ from the reactions of respectively 180 , 200 and $220{ }^{\circ} \mathrm{C}$ for $30 \mathrm{~min}$ were observed [17]. These results seemed compatible with this study. Additionally, higher heating values were obtained with higher reaction times ( 3 and $4 \mathrm{~h}$ ).

As in literature, torrefaction of olive pomace at higher temperatures provided greater higher heating values. In a study on olive pomace $\left(26.4 \mathrm{MJ} / \mathrm{kg}\right.$ of $\mathrm{HHV}$ ) at 200,250 and $300{ }^{\circ} \mathrm{C}$ for 2 hours HHV results were obtained as respectively 26.5, 28.7 and 29.4 $\mathrm{MJ} / \mathrm{kg}$ [15]. However, these results were measured as high as this because of the olive pomace used in that study consists $26 \%$ of olive oil.

Guizani et al. (2016) carried out another study with olive pomace which contained similar energy amount as the olive pomace used for this study. HHV of 20.50, 21.9, 22.7, 23.7 and $25.8 \mathrm{MJ} / \mathrm{kg}$ were obtained by the torrefaction reactions at respectively 230 , 250, 270, 290 and $310^{\circ} \mathrm{C}$ for 1 hour [16]. These results showed similarity with the higher heating values obtained in this study.

The main aim of using these conversion methods was to increase the energy yields. However, it is crucial to evaluate the mass yields for economic reasons. Mass yields were reduced with the increasing temperature values. During HTC processes, above the $200{ }^{\circ} \mathrm{C}$, mass yields remained stable around $60 \%$. At 300 and $350{ }^{\circ} \mathrm{C}$, mass yields of torrefaction processes were measured between $29-35 \%$. These dramatic decreases on mass yields of torrefaction above $250{ }^{\circ} \mathrm{C}$ are similar for some other studies. It is 
observed that obtaining higher energy contents at lower temperatures makes hydrochar obtained from HTC process a more desirable solid fuel than biochar.

\section{Conclusions}

Higher heating values of torrefaction at $275^{\circ} \mathrm{C}$ for 20 minutes and hydrothermal carbonization at $220^{\circ} \mathrm{C}$ for 2 hours were measured as respectively 23.73 and $25.20 \mathrm{MJ} / \mathrm{kg}$ for the same energy yield value of $62 \%$. It is concluded that HTC process provides an energy-dense solid biofuel from olive pomace under lower temperature values, without a pre-drying process. The ash content of hydrochars was observed to be decreased while the ash content of biochars increased. HTC process has the advantage to generate high quality solid biofuels with lower ash content. The lower ash amount of biofuel provides the higher combustion, gasification and pyrolysis performances.

According to the HTC results, the residence time didn't show a significant effect on proximate and elemental analysis results of hydrochars. Therefore, it is suggested to perform experiments with shorter residence times for further studies. However, in order to make a more accurate comparison with torrefaction, performing higher temperature degrees (around $250{ }^{\circ} \mathrm{C}$ ) for HTC experiments are recommended. The available commercial hydrothermal carbonization systems are very limited because of some engineering problems. It's also recommended to establish pilot HTC systems for further studies. Also, developing solar energy integrated systems might reduce the costs for both methods.

\section{Acknowledgement}

This study was supported by Ege University Scientific Research Projects Coordination Unit (Project Number:15GEE008) and The Scientific and Technological Research Council of Turkey (Project Number: 213M527).

\section{References}

[1] International Energy Agency. World Energy Outlook Executive Summary. France; 2016.

[2] Liu Z, Han G (2005), Production of solid fuel biochar from waste biomass by low temperature pyrolysis. Fuel 65, 158-159.

[3] Nhuchhen DR, Basu P, Acharya B. A Comprehensive Review on Biomass Torrefaction. International Journal of Renewable Energy \& Biofuels Vol. 2014

[4] Bach QV, Tran KQ, Skreiberg Ø, Khalil RA, Phan AN (2014), Effects of wet torrefaction on reactivity and kinetics of wood under air combustion conditions. Fuel 137, 375-383.

[5] Yan W, Perez S, Sheng K (2017), Upgrading fuel quality of moso bamboo via low temperature thermochemical treatments: Dry torrefaction and hydrothermal carbonization. Fuel 196, 473-480.

[6] Gao Y, Wang X, Wang J, Li X, Cheng J, Yang H (2013), Effect of residence time on chemical and structural properties of hydrochar obtained by hydrothermal carbonization of water hyacinth Energy 58, 376-383.

[7] Bach QV, Skreiberg O (2016), Upgrading biomass fuels via wet torrefaction: A review and comparison with dry torrefaction. $R e$ newable and Sustainable Energy Reviews 54, 665-677.

8] Kambo HS, Dutta A (2014), Strength, storage, and combustion characteristics of densified lignocellulosic biomass produced via torrefaction and hydrothermal carbonization. Applied Energy 135 , 182-191.

[9] Aktas ES, Imre S, Ersoy L (2001), Characterization and lime treatment of olive mill wastewater. Water. Res. 35, 2336-2340.

[10] Chowdhury AKMMB, Konstantinou F, Damati A, Akratos CS, Vlastos D, Tekerlekopoulou AG, Vayenas DV (2015), Is physicochemical evaluation enough to characterize olive mill waste compost as soil amendment? The case of genotoxicity and cytotoxicity evaluation. Journal of Cleaner Production 93, 94-102.

[11] Roig A, Cayuela ML, Sánchez-Monedero MA (2006), An overview on olive mill wastes and their valorisation methods. Waste Management 26, 960-969.
[12] Niaounakis M, Halvadakis CP. Olive Mill Waste Management Literature Review and Patent Survey. Typothito, George Dardanos Publications. Athens; 2004.

[13] Kavroulakis N, Ntougias S (2010), Bacterial and $\beta$ proteobacterial diversity in Olea europaea var. mastoidis- and $\mathrm{O}$. europaea var. koroneiki-generated olive mill wastewaters: influence of cultivation and harvesting practise on bacterial community structure. World J. Microbiol. Biotechnol. 27, 57-66.

[14] Poerschmann J, Baskyr I, Weiner B, Koehler R, Wedwitschka H, Kopinke FD (2013), Hydrothermal carbonization of olive mill wastewater. Bioresource Technology 133, 581-588.

[15] Benavente V, Fullana A (2015), Torrefaction of olive mill waste. Biomass and Bioenergy 73, 186-194.

[16] Guizani C, Haddad K, Jeguirim M, Colin B, Limousy L (2016), Combustion characteristics and kinetics of torrefied olive pomace. Energy 107, 453-463

[17] Volpe M, Fiori L (2017), From olive waste to solid biofue through hydrothermal carbonisation: The role of temperature and solid load on econdary char formation and hydrochar energy properties. Journal of Analytical and Applied Pyrolysis 124, $63-$ 72.

[18] Pala M, Kantarli IC, Buyukisik HB, Yanik J (2014), Hydrothermal carbonization and torrefaction of grape pomace: A comperative evaluation. Bioresource Technology 161, 255-262.

[19] Wilk M, Magdziarz A (2017), Hydrothermal carbonization, torrefaction and slow pyrolysis of Mischantus giganteus. Energy 140(1), 1292-1304.

[20] Liu Z, Quek A, Hoekman SK, Srinivasan MP, Balasubramanian R (2012), Thermogravimetric investigation of hydrochar-lignite co-combustion. Bioresour. Technol. 123, 646-652.

[21] Bach QV, Tran KQ, Skreiberg Ø, Trinh TT (2015), Effects of wet torrefaction on pyrolysis of woody biomass fuels. Energy 88, 443-456

[22] Tremel A, Stemann J, Hermann M, Erlach B, Spliethoff H (2012), Entrained flow gasification of biocoal from hydrothermal carbonization. Fuel 102, 396-403.

[23] Dai J, Sokhansanj S, Grace JR, Bi X, Lim CJ, Melin S (2008) Overview and some issues related to co-firing biomass and coal. Can. J. Chem. Eng. 86, 367-386.

[24] Nachenius RW, van de Wardt TA, Ronsse F, Prins W (2015), Torrefaction of pine in a bench-scale screw conveyor reactor. $B i$ omass and Bioenergy 79, 96-104

[25] Mei Y, Liu R, Yang Q, Yang H, Shao J, Draper C, Zhang S, Chen $H$ (2015), Torrefaction of cedarwood in a pilot scale rotary kiln and the influence of industrial flue gas. Bioresource Technology 177, 355-360.

[26] Prins MJ, Ptasinski KJ, Janssen FJJG (2006), More efficient biomass gasification via torrefaction. Energy 31, 3458-3470.

[27] Ciolkosz D, Wallace R (2011), A review of torrefaction for bioenergy feedstock production. Biofuels, Bioproducts and Biorefining 5(3), 317-329.

[28] Funke A, Ziegler F (2010), Hydrothermal carbonization of biomass: a summary and discussion of chemical mechanisms for process engineering. Biofuel. Bioprod. Bior. 4, 4160-4177.

[29] Hoekman SK, Broch A, Robbins C (2011), Hydrothermal Carbonization (HTC) of Lignocellulosic Biomass. Energy Fuels 25 1802-1810.

[30] Lu X, Pellechia PJ, Flora JRV, Berge ND (2013), Influence of reaction time and temperature on product formation and characteristics associated with the hydrothermal carbonization of cellulose Bioresource Technology 138, 180-190. 